\title{
Intraspecific Root Grafts and Clonal Growth Within Ailanthus altissima Stands Influence Verticillium nonalfalfae Transmission
}

\author{
E. S. O'Neal and D. D. Davis, Department of Plant Pathology and Environmental Microbiology, The Pennsylvania State University, University \\ Park 16802
}

\begin{abstract}
O’Neal, E. S., and Davis, D. D. 2015. Intraspecific root grafts and clonal growth within Ailanthus altissima stands influence Verticillium nonalfalfae transmission. Plant Dis. 99:1070-1077.

Verticillium nonalfalfae, causal agent of Verticillium wilt, is being considered as a biocontrol for the highly invasive Ailanthus altissima in Pennsylvania. This soilborne fungus is extremely virulent on Ailanthus and rapidly transmitted from diseased to healthy trees within Ailanthus stands. The rapid transmission of the fungus could be facilitated by root grafts, but neither root graft formation in Ailanthus nor Verticillium transmission by root grafts in trees has been reported. Here, $V$. nonalfalfae transmission between diseased and healthy Ailanthus trees via intraspecific root grafts and clonal growth is evaluated. Using air-spade excavation, dye

translocation, and root graft inoculations, functional root grafts were detected between Ailanthus trees and transmission of $V$. nonalfalfae across root grafts demonstrated. Inoculation of one Ailanthus parent stem resulted in 187 root sprouts showing Verticillium wilt symptoms 12 months after inoculation. This study revealed that clonal growth and root grafts, normally advantageous growth habits, leave Ailanthus stands vulnerable to widespread $V$. nonalfalfae infection. This study also broadens the understanding of the Ailanthus-Verticillium pathosystem, growth strategies of invasive Ailanthus, and epidemiology of Verticillium wilt within trees.
\end{abstract}

Tree-of-heaven, Ailanthus altissima (Mill.) Swingle, is an aggressive exotic invader of forest and urban environments across the United States. Since introduction into Philadelphia in 1784, this shade-intolerant tree has become especially populous in the Mid-Atlantic region $(11,22)$. Historically, Ailanthus was mainly found along transportation corridors and in urban areas, where it remains problematic. In addition, Ailanthus has recently invaded and increased in number within forested areas (22), where fast growth, prolific seed production, clonal proliferation, and allelopathy has enabled Ailanthus to displace desirable native plant species $(8,17,31)$. Presently, attempts to control Ailanthus rely primarily on the use of chemical herbicides, which are expensive, laborious, often ineffective, and require repetitive applications. In recent years, Verticillium wilt caused by Verticillium nonalfalfae Inderbitzin et al., a soilborne, vascular wilt pathogen, has been proposed as an effective, hostadapted, biological control for Ailanthus $(24,25,40)$.

$V$. nonalfalfae, previously classified as $V$. albo-atrum Reinke and Berthold, has been reported to infect hops, spinach, solanaceous crops, and various trees in the United States, the United Kingdom, Canada, Slovenia, and Japan $(16,19,24,25,35,41)$. In Pennsylvania, Virginia, and Ohio, $V$. nonalfalfae has been isolated from wilting and dying Ailanthus trees and appears native to eastern forests $(25,37,43,44)$. Infected Ailanthus trees exhibit yellow vascular discoloration and acute foliage wilt, followed by defoliation, and eventual mortality. Etiology and efficacy studies have shown that $V$. nonalfalfae isolate VnAa140 is extremely virulent on Ailanthus, and comparative pathogenicity and host range testing revealed that the isolate appears to be hostadapted to Ailanthus $(24,25,41)$. However, very low incidences of natural infection have been observed in striped maple (Acer pensylvanicum L.), staghorn sumac (Rhus typhina L.), and devil's walking stick (Aralia spinosa L.) within severely infected Ailanthus stands, indicating that these three species may serve as minor, native, alternative hosts (24).

Corresponding author: D. D. Davis, E-mail: ddd2@psu.edu

*The $\boldsymbol{e}$-Xtra logo stands for "electronic extra" and indicates that three supplementary figures are included in the online edition.

Accepted for publication 6 October 2014.

http://dx.doi.org/10.1094/PDIS-07-14-0722-RE

C 2015 The American Phytopathological Society
In both naturally infected and artificially inoculated Ailanthus stands, $V$. nonalfalfae is rapidly transmitted from diseased to healthy trees by undetermined modes. During the spring seasons of 2006 to 2009, the inoculation of 100 Ailanthus trees across 12 stands resulted in the infection and mortality of $>14,000$ Ailanthus stems by fall of 2011. In one of these stands, $V$. nonalfalfae was transmitted from only 10 inoculated Ailanthus trees to $>300$ adjacent, formerly healthy Ailanthus trees within 1 year after inoculation (25). We hypothesized that the modes of rapid $V$. nonalfalfae transmission, both local and long-distance, may include insect vectors (ambrosia beetles); infected leaves, seeds, and wood; root contact $(12,20,30,38)$; clonal root systems; and intraspecific root grafts $(23,25,39)$. The latter two potential modes of transmission are the focus of this study.

Root grafts between trees are initiated when opposing mature roots first come in contact. The respective cortexes then rupture from the pressure caused by root diameter expansion that is constricted by soil and rock. Next, the cambia come into contact and vascular tissues fuse $(4,27,32,33)$. Ecologically, root grafts between or among trees can influence tree growth, forest succession, stand development, and forest management practices $(9,15,48)$. Root grafts are generally advantageous adaptations for trees (28), but transmission of many well-known forest pathogens can occur through root grafts $(5,10)$. For example, Ceratocystis fagacearum (Bretz) J. Hunt, causal agent of oak wilt, and Ophiostoma ulmi (Buis.) Melin and Nannfeldt, causal agent of Dutch elm disease, can be transmitted from diseased to healthy trees by intraspecific root grafts $(18,49)$. Other wilt diseases such as persimmon wilt, caused by Acremonium diospyri (Crand.) W. Gams, and laurel wilt, caused by Raffaelea lauricola T.C. Harr., Fraedrich, and Agaveya, might also be transmitted by root grafts and clonal root systems. However, evidence for root graft transmission of $A$. diospyri and $R$. lauricola is limited and requires further study $(6,36)$.

Although root grafts have not been reported to transmit Verticillium spp. from diseased to healthy trees, Epstein (10) reviewed this possibility. Intraspecific root grafts have not been reported in A. altissima, but there is circumstantial evidence that such grafts occur. For example, Lewis and McCarthy (29) reported that herbicide applications of select Ailanthus trees resulted in the death of adjacent, untreated Ailanthus trees, presumably by herbicide translocation through root grafts between treated and untreated trees. Also, Schall (39) observed that noninoculated Ailanthus trees adjacent to Ailanthus trees artificially inoculated with $V$. nonalfalfae developed wilt symptoms within 
2 weeks after the inoculated trees wilted. These observations indicate that intraspecific root grafts and/or clonal root systems may be important in the rapid, localized transmission of $V$. nonalfalfae from diseased to healthy Ailanthus trees. Herein we provide the first evidence of functioning intraspecific root grafts in Ailanthus and movement of Verticillium through the grafts.

The main objectives of this study were to (i) determine if Ailanthus naturally forms functional intraspecific root grafts, (ii) estimate the frequency of intraspecific root grafts within Ailanthus stands, (iii) determine if $V$. nonalfalfae can be transmitted from tree-to-tree by intraspecific root grafts, and (iv) determine if $V$. nonalfalfae can be transmitted through clonal root systems of Ailanthus.

\section{Materials and Methods}

Study sites. Three Ailanthus stands, differing in age and size of Ailanthus trees, located in south-central Pennsylvania among mixedhardwood dominated forests, were selected for the root graft studies.

The first Ailanthus stand, LV, was even-aged and located in Locke Valley near Shade Gap, PA, within Rothrock State Forest (Huntingdon Co.). The mean age of Ailanthus trees was 11.8 years and mean diameter at breast height (DBH, $1.4 \mathrm{~m}$ ) was $11.7 \mathrm{~cm}$. The mean basal area for Ailanthus trees within the stand was $23.0 \mathrm{~m}^{2} / \mathrm{ha}$.

The second stand, SGL 322, was a mixed-aged stand located on State Game Lands 322 near Petersburg, PA (Huntingdon Co.). The mean age of Ailanthus trees was 37.6 years, mean DBH was $12.2 \mathrm{~cm}$, and mean basal area for Ailanthus trees was $22.5 \mathrm{~m}^{2} / \mathrm{ha}$. This stand also contained many small Ailanthus saplings and young root sprouts, in addition to a few old large canopy Ailanthus trees.

The third stand, SGL 281, was located on State Game Lands 281 near Newport, PA (Perry Co.). This even-aged stand was larger, denser, and older than the other two study stands. Mean Ailanthus tree age was 38.9 years, mean DBH was $17.3 \mathrm{~cm}$, and mean basal area for Ailanthus trees was $32.6 \mathrm{~m}^{2} / \mathrm{ha}$.

Detection of root grafts using dye translocation. Methods used to detect functional intraspecific root grafts in Ailanthus stands were modified from protocols reported by Bormann and Graham (4) and Graham (14). In May 2013, five circular 5-m radius plots per stand were established in stands LV, SGL 322, and SGL 281.

An Ailanthus tree in the middle of each plot was selected, based on size and proximity to neighboring Ailanthus stems, and designated as plot center. Diameters of all Ailanthus stems $>2.54 \mathrm{~cm} \mathrm{DBH}$ in each plot were recorded, as well as distance of each stem from the plot center. In each plot, the plot center stem was felled, leaving an approximately $30-\mathrm{cm}$ tall "donor" stump. A $30-\mathrm{cm}$ tall dye reservoir was constructed on each donor stump using vinyl roof flashing, staples, and caulk. Reservoirs were filled with $0.15 \%$ aqueous acid fuchsin dye solution. Each reservoir was capped and covered with plastic sheeting to prevent evaporation (Supplementary Fig. 1). Dye was maintained at a depth of $13 \mathrm{~cm}$ for 6 weeks, at which time a 20 -cm wide strip of bark around the circumference on all Ailanthus stems within each plot was removed. Stems that received dye from the donor stump were designated "receptor" stems and those that did not were designated "non-receptor" stems. The ages of all receptor stems and felled donor stems were determined at DBH using 5.15-mm diameter increment borers (Haglof Company Group, Madison, MS). Extracted cores were mounted, sanded, and aged by counting annual growth rings as described by Kasson et al. (22).

Air-spade excavation of Ailanthus root systems. In early June 2013, an air-spade (Guardair Corp., Chicopee, MA) and a towable 185 CFM air compressor (Sullair, Michigan City, IN) were used to excavate the root systems of 16 Ailanthus trees in stand LV to determine presence and estimate frequency of intraspecific root grafts. Stand LV was judged most suitable for excavation due to its accessibility and lack of large stones. Ailanthus trees to be excavated were selected based on size and proximity to other Ailanthus trees. Herbaceous vegetation, if present, within a $2-\mathrm{m}$ radius around each selected stem was removed and soil excavated to a depth of approximately $40 \mathrm{~cm}$ with the air-spade. Any two Ailanthus roots, each originating from a separate stem, that appeared to be grafted and could not be easily separated by hand were tallied as intraspecific root grafts.
Culture maintenance, inoculum preparation, and isolation. Protocols for $V$. nonalfalfae culture maintenance and inoculum preparation followed those reported by Kasson et al. (25) and Schall and Davis (40). V. nonalfalfae was grown in petri dishes containing plum extract agar (PEA) (46) amended with streptomycin sulfate and neomycin sulfate $(\mathrm{PEA}+\mathrm{SN})(25,40)$ in a controlled environment chamber maintained at $23^{\circ} \mathrm{C}$ with a 12-h photoperiod.

After 4 weeks, 5 to $10 \mathrm{ml}$ sterile distilled water was added to the surface of actively growing cultures. Mycelia and conidia were loosened from the agar with a sterile spatula and pipetted in 3-ml aliquots into 10-ml scintillation vials containing a 1:1:1 mixture (by volume) of sterile potting soil-perlite-peat moss. The mixture had been previously autoclaved for $1 \mathrm{~h}$ on at least three or more consecutive days and prewetted with $2 \mathrm{ml}$ sterile distilled water. Vials were loosely capped and stored on the laboratory bench at room temperature for 2 weeks to allow $V$. nonalfalfae colonization of the mixture. After 2 weeks, the vials were tightly capped and stored at $4^{\circ} \mathrm{C}$. To remove isolates from storage, soil particles were tapped from vials onto fresh PEA+SN petri dishes. Within 3 to 5 days, resulting colonies were transferred to new PEA+SN dishes. $V$. nonalfalfae isolates stored following this protocol remain viable after $>4$ years of storage (E. S. O'Neal, unpublished data).

To produce inoculum, 3-week-old $V$. nonalfalfae isolate VnAa140 cultures were flooded with $10 \mathrm{ml}$ sterile distilled water and scraped with a sterile spatula to loosen mycelia and conidia. The resultant suspension was collected, vortexed, and passed through a milk filter (KenAg, Ashland, $\mathrm{OH}$ ) to remove mycelial fragments. Conidial concentration was determined using a hemocytometer and adjusted to $10^{7}$ conidia $\mathrm{ml}^{-1}$ by adding sterile distilled water to the suspension. Viability of resulting inoculum was determined by counting colony forming units (CFU) from 10-fold serial dilutions on PEA+SN dishes. Inoculum exhibiting $>80 \%$ conidial viability was stored at $4^{\circ} \mathrm{C}$ until used in the field. Pathogenicity of $V$. nonalfalfae isolate VnAa140 was maintained by annually inoculating 1-month-old potted Ailanthus seedlings in a greenhouse with VnAa140 conidial suspension. Following inoculation, symptomatic stems were destructively sampled, disinfested with $70 \%$ ethanol, and inserted into fresh PEA+SN dishes, where $V$. nonalfalfae was subsequently reisolated into pure culture for use as inoculum.

To confirm infections following field inoculations and symptom development, $V$. nonalfalfae was isolated by removing bark and excising discolored wood chips from symptomatic roots or stems with a disinfested knife. Chip samples were bagged, placed in coolers, and surface-disinfested in the laboratory with $70 \%$ ethanol. Samples were reduced in size with sterile cutting instruments to remove outer surfaces, exposing the inner wood, and inserted into PEA+SN dishes. After 10 days, emerging colonies exhibiting morphological characteristics of $V$. nonalfalfae (e.g., verticillate conidiophores and melanized resting mycelia) were transferred to fresh $\mathrm{PEA}+\mathrm{SN}$ dishes to obtain pure cultures that were stored and later used for molecular identification.

DNA extraction and molecular identification of isolates. Genomic DNA was extracted from air-dried mycelial plugs harvested from potato dextrose broth (PDB) (BD, Franklin Lakes, NJ) using a Wizard Genomic DNA Purification Kit (Promega Corp., Madison, WI), following procedures used by Kasson et al. (25). Isolate identification was based on PCR protocols reported by Inderbitzin et al. (19). A Nyx Technik ATC 201 Programmable Thermal Cycler (Nyx Technik, Inc., San Diego, CA), GoTaq PCR kits (Promega Corp., Madison, WI), and Platinum Taq (Invitrogen, Carlsbad, CA) were used to amplify three loci: the protein-coding genes elongation factor $1-\alpha(\mathrm{EF})$, glyceraldehyde-3-phosphate dehydrogenase (GPD), and tryptophan synthase (TS). Amplified PCR products were electrophoresed in $2 \%$ agarose gels and stained with EZ-Vision Three DNA Dye \& Buffer $6 \times$ (AMRESCO, Solon, OH) to visualize bands. PCR products were purified using ExoSAP-IT (Affymetrix, Santa Clara, CA). At the Pennsylvania State University Genomics Core Facility, Sanger sequencing was conducted on an ABI $3730 \mathrm{XL}$ automated DNA sequencer (Applied Biosystems, Carlsbad, CA). Sequencher 4.8 (Gene Codes, Ann Arbor, MI) was used to revise the raw sequence data and assemble consensus sequences before used as BLAST queries to search against the NCBI GenBank database for isolate identification. 
Intraspecific root graft inoculations. In late May to mid-June 2013, 12 previously discovered intraspecific root grafts were fully excavated within Ailanthus stands SGL 281 and LV. Vegetation and soil were removed from around the roots to expose the graft unions (Fig. 1A), and each grafted root was traced to its parent stem. Grafts were rinsed with distilled water to remove any additional soil. One root, designated the "donor" root, was severed on both sides of the graft union. This created a free root segment connected to an intact root, designated the "receptor" root, only by the graft union (Fig. 1B). Severing the donor roots was conducted to ensure that $V$. nonalfalfae would enter the receptor roots and stems only via the graft unions.

Both cut surfaces of the donor root were sealed with grafting wax (Trowbridge's, Walter E. Clark \& Son, Orange, CT) to reduce desiccation. Ten donor roots were each inoculated with a conidial suspension $\left(10^{7}\right.$ conidia $\left.\mathrm{ml}^{-1}\right)$ of $V$. nonalfalfae isolate VnAa140 at two locations, between each cut surface and the graft union. Inoculation points received $0.5 \mathrm{ml}$ inoculum in a wound made with a $0.75-\mathrm{cm}$ diameter cork borer (Fig. 1C).

A variation of this protocol was used on intraspecific root grafts that formed within the base of Ailanthus stems, where a root grew into and fused with the base of a neighboring stem. In those cases, the
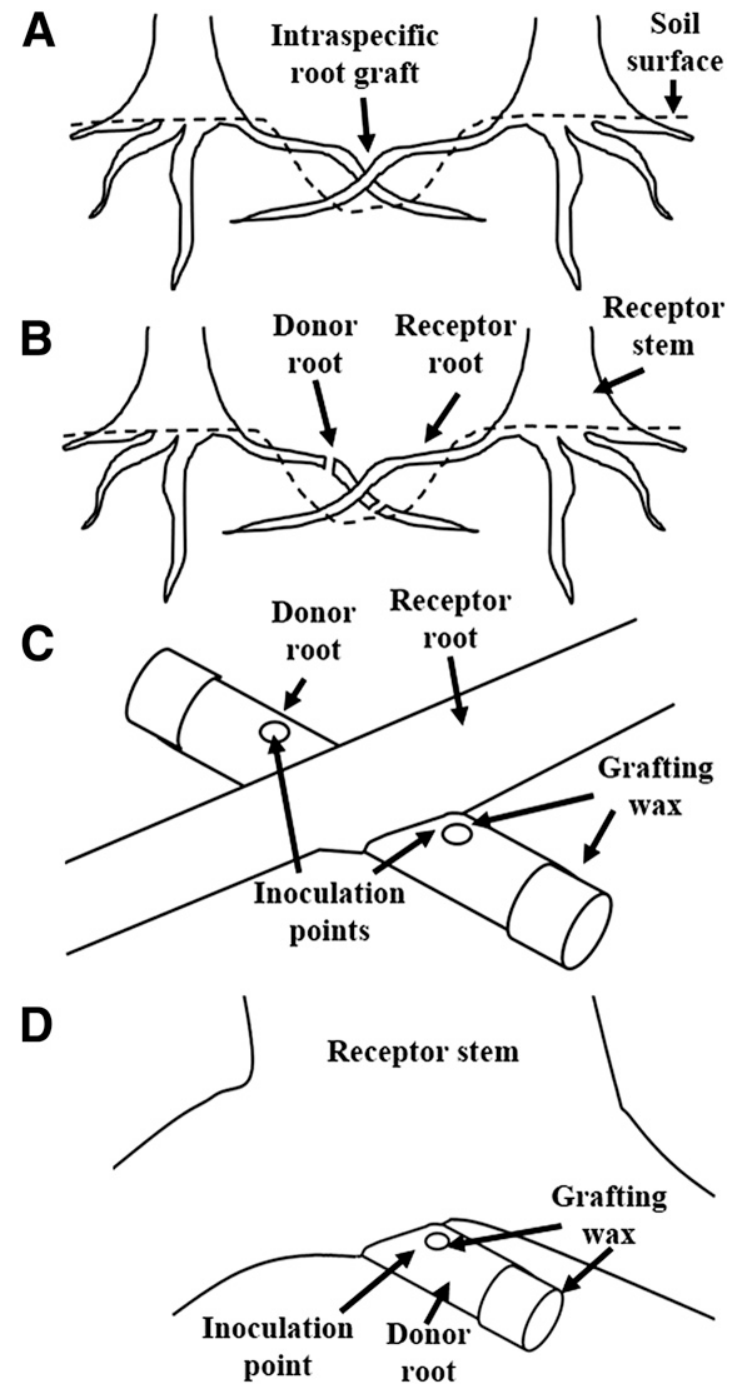

Fig. 1. Methods used to inoculate Ailanthus intraspecific root grafts with Verticillium nonalfalfae isolate $\mathrm{VnAa} 140$. The diagram shows $\mathrm{A}$, the excavation of the intraspecific root graft from soil; B, severing of the donor root and designation of the receptor root and stem; $\mathbf{C}$, inoculation points, each receiving $0.5 \mathrm{ml} \mathrm{V}$. nonalfalfae isolate VnAa140 conidial suspension $\left(10^{7}\right.$ conidia $\left.\mathrm{Il}^{-1}\right)$, sealing of the inoculation points and wounds created by severing the donor root with grafting wax; and D, a modified inoculation method used to inoculate intraspecific root grafts that occur within the base of an Ailanthus stem. donor root was severed, creating a root stub protruding from the stem base. This stub was inoculated only in one location, between the stem base and the cut surface, with $0.5 \mathrm{ml}$ conidial suspension (Fig. 1D). The remaining two donor roots served as negative controls and were treated with sterile distilled water. A plastic sheet was placed under each intraspecific root graft during inoculation and for the duration of the experiment to prevent inoculum from contacting the soil.

Once the donor root absorbed the inoculum, the severed root faces and inoculation wounds were sealed with grafting wax to reduce desiccation (Fig. 1C and D). Each graft, including the entire donor root, was wrapped in a white cotton cloth to minimize $V$. nonalfalfae contact with soil and reduce root desiccation. When the parent stem of the receptor root, designated the "receptor" stem, exhibited acute wilt symptoms ( $>15 \%$ wilt of the total foliage) the bark was removed from the receptor stem and root, in addition to the donor root to inspect for yellow vascular discoloration. Wood chip samples were taken from discolored wood in the receptor stems and roots, as well as associated donor roots. These samples were then cultured on $\mathrm{PEA}+\mathrm{SN}$ dishes to reisolate $V$. nonalfalfae. In addition, the root grafts involved in $V$. nonalfalfae transmission were destructively sampled and examined for shared vascular tissues (13). All receptor stems were monitored biweekly for Verticillium wilt symptoms until June 2014, at which time remaining inoculated root grafts were destructively sampled and examined to determine if they were functional, indicated by shared vascular tissues.

Ailanthus clone inoculation. In early June 2013, a fourth study site was selected to study $V$. nonalfalfae transmission within a relatively small, nearly pure Ailanthus clone. This new site was located on the Raystown Lake Project, U.S. Army Corps of Engineers (USACE) land near Hesston, PA (Huntingdon Co.). The stand consisted of two male (non-seed producing) Ailanthus parent stems and $>200$ suspected Ailanthus clonal root sprouts $<2.54 \mathrm{~cm} \mathrm{DBH}$. Root sprouts differ from root grafts in that a root sprout is a vegetative shoot that arises directly from parent stem's roots, thus already sharing vascular tissues.

The larger of the two male parent stems $(24.3 \mathrm{~cm} \mathrm{DBH}, 14$ years old) at the stand center was inoculated by injecting $3 \mathrm{ml} V$. nonalfalfae isolate VnAa140 conidial suspension $\left(10^{7}\right.$ conidia $\left.\mathrm{ml}^{-1}\right)$ into three basal wounds ( $1 \mathrm{ml} /$ wound) with a hypo-hatchet (OEM Fabricators Inc., Woodville, WI). All surrounding Ailanthus stems $>0.5 \mathrm{~m}$ in height, as well as both parent stems, a total of 213 stems, were flagged for monitoring. As stems exhibited Verticillium wilt symptoms, they were flagged with a different color and tallied. Stems that exhibited $>15 \%$ wilt of the total foliage were rated as symptomatic; stems that had $<15 \%$ wilted foliage were rated as asymptomatic. A tally of symptomatic stems was generated monthly (with an additional tally generated in mid-September 2013) through June 2014 to monitor the spread of $V$. nonalfalfae throughout the Ailanthus clone. In May 2014, wood samples were taken from 10 symptomatic stems surrounding the inoculated parent stem to reisolate $V$. nonalfalfae.

\section{Results}

Detection of root grafts in three stands using dye translocation. Results from the dye translocation study revealed that Ailanthus frequently forms functional intraspecific root grafts, even within young stands like LV. Dye translocation was observed within all three study stands, as evidenced by purple dye in the xylem of Ailanthus receptor stems (Fig. 2). Thirteen of 15 donor stumps (87\%) donated dye to at least one receptor stem, and nine of the 13 donor stumps (69\%) donated dye to the nearest Ailanthus stem. Thirty-five receptor stems were observed: nine in stand LV, nine in stand SGL 322, and 17 in stand SGL 281 (Tables 1, 2, and 3). Occasionally, multiple dark streaks of dye were observed in single stems (Fig. 2, Supplementary Fig. 2). Dissection of donor stumps revealed that downward dye movement occurred only in a few outer growth rings, even though the entire cut stump surface was in contact with dye (Supplementary Fig. 3).

In the youngest Ailanthus stand, LV, four of the five Ailanthus donor stumps donated dye to at least one receptor stem (Table 1). No visible dye was observed in any potential receptor stems in the remaining plot. The mean number of receptor stems was 1.8 receptor 
stems per donor stump. The mean stem DBH of the five donor stumps was $15.1 \mathrm{~cm}$ (range: 12.6 to $22.1 \mathrm{~cm}$ ). The mean receptor stem DBH was $11.8 \mathrm{~cm}$ (range: 6.8 to $16.3 \mathrm{~cm}$ ). The mean distance between the donor stumps and receptor stems was $1.24 \mathrm{~m}$ (range: 0.40 to $2.15 \mathrm{~m}$ ). The four donor stumps that donated dye did so to the nearest Ailanthus stem (Table 1).

In the mixed-aged stand, SGL 322, all five Ailanthus donor stumps donated dye to at least one receptor stem, and had a mean of 1.8 receptor stems/donor stump (Table 2). The mean stem DBH of the donor stumps was $18.2 \mathrm{~cm}$ (range: 14.6 to $24.3 \mathrm{~cm}$ ). The mean receptor stem DBH was $18.5 \mathrm{~cm}$ (range: 8.2 to $25.6 \mathrm{~cm}$ ). The mean distance between donor stumps and receptor stems was $1.5 \mathrm{~m}$ (range: 0.65 to $2.20 \mathrm{~m}$ ). Unlike stand LV, only two of the five donor stumps donated dye to the nearest Ailanthus stem (Table 2).

Lastly, in the older even-aged stand, SGL 281, four of five Ailanthus donor stumps had at least one receptor stem. The mean number of receptor stems was 3.4 stems/donor stump (Table 3). The mean stem DBH of the donor stumps was $22.3 \mathrm{~cm}$ (range: 20.7 to $25.3 \mathrm{~cm}$ ). Mean receptor stem DBH was $19.6 \mathrm{~cm}$ (range: 5.4 to $29.1 \mathrm{~cm}$ ). Greater distances between donor stumps and receptor stems were observed in this stand, as compared with the other two stands. The mean distance between the donor stumps and the receptor stems was $2.60 \mathrm{~m}$ (range: 0.95 to $5.00 \mathrm{~m}$ ), which was double the mean distance between stems in stand LV (Tables 1 and 3). Eight of 17 (47\%) receptor stems were $\geq 2.5 \mathrm{~m}$ from their donor stumps. In addition, three of four donor stumps that donated dye did so to the nearest Ailanthus stem. There were no receptor stems in plot 2 (Table 3), even though a largediameter neighboring stem $(28.0 \mathrm{~cm} \mathrm{DBH})$ was present within a few meters $(1.95 \mathrm{~m})$ from the large donor stump $(21.8 \mathrm{~cm} \mathrm{DBH})$.

Air-spade excavation of Ailanthus root systems. Of the $16 \mathrm{Ai}$ lanthus root systems excavated, 12 (75\%) formed at least one intraspecific root graft with a neighboring Ailanthus stem (Table 4). Excavation revealed a total of 28 intraspecific Ailanthus root grafts, which represented a mean of 1.8 root grafts per stem (Table 4). The number of root grafts excavated per stem ranged from one to seven. The mean distance between root-grafted stems was $1.08 \mathrm{~m}$ (range: 0.55 to $2.04 \mathrm{~m}$ ). Seventy-five percent of the stems that formed intraspecific root grafts formed them with the nearest Ailanthus stem. Root systems of stems 9 and 14 formed root grafts with the nearest Ailanthus stem and one additional nearby stem (Table 4). Intraspecific root grafts were not observed in the root systems of stems 1 , 2, 4, and 12 (Table 4). Six (38\%) of the 16 excavated Ailanthus root systems formed a total of 11 self-grafts. Interspecific root grafts between A. altissima and other tree species were not observed.

Intraspecific root graft inoculations. In May 2013, 10 excavated Ailanthus intraspecific root grafts were inoculated with $V$. nonalfalfae isolate VnAa140. Of the inoculated root grafts, three receptor

Table 1. Dye translocation observed within the even-aged 11-year-old Ailanthus stand, LV

\begin{tabular}{|c|c|c|c|c|c|}
\hline \multirow{2}{*}{ Plot } & \multirow{3}{*}{$\begin{array}{l}\begin{array}{l}\text { Donor } \\
\text { stump }\end{array} \\
\begin{array}{l}\text { DBH } \\
(\mathbf{c m})^{\mathbf{b}}\end{array}\end{array}$} & \multicolumn{2}{|c|}{ Receptor stems $^{\mathbf{a}}$} & \multicolumn{2}{|c|}{$\begin{array}{c}\text { Nearest } \\
\text { non-receptor stem }\end{array}$} \\
\hline & & \multirow[b]{2}{*}{ DBH (cm) } & \multirow{2}{*}{$\begin{array}{l}\text { Distance } \\
\text { from donor } \\
\text { stump (m) }\end{array}$} & \multirow{2}{*}{$\begin{array}{c}\text { DBH } \\
(\mathbf{c m})\end{array}$} & \multirow{2}{*}{$\begin{array}{c}\text { Distance } \\
\text { from donor } \\
\text { stump }(m)\end{array}$} \\
\hline ID & & & & & \\
\hline 1 & 12.6 & 12.0 & 0.90 & 14.0 & 1.05 \\
\hline 2 & 15.3 & - & - & 7.1 & 1.10 \\
\hline \multirow[t]{3}{*}{3} & 13.1 & 16.0 & 0.80 & 14.5 & 1.05 \\
\hline & & 8.6 & 1.40 & & \\
\hline & & 15.5 & 2.00 & & \\
\hline \multirow[t]{3}{*}{4} & 12.6 & 12.5 & 0.40 & 7.2 & 0.50 \\
\hline & & 6.8 & 1.05 & & \\
\hline & & $7.1,10.3,11.7$ & 1.25 & & \\
\hline \multirow[t]{2}{*}{5} & 22.1 & 16.3 & 1.25 & 15.3 & 2.75 \\
\hline & & 13.2 & 2.15 & & \\
\hline Average & 15.1 & 11.8 & 1.24 & 11.6 & 1.29 \\
\hline
\end{tabular}

stems $(30 \%)$ displayed symptoms characteristic of Verticillium wilt (Fig. 3A), becoming symptomatic at 2, 4, and 12 weeks postinoculation (WPI). The three symptomatic stems developed yellow vascular discoloration that extended distally into the receptor roots, graft unions, and donor roots (Fig. 3B and C). V. nonalfalfae was successfully isolated from symptomatic receptor trees and their associated donor roots, confirming transmission of the pathogen. The remaining seven receptor stems were asymptomatic through June 2014, at which time sampling and dissection revealed that four of the seven grafts were not functional. The two control stems remained asymptomatic.

Inoculation of the Ailanthus clone. Inoculation of one Ailanthus parent stem with $V$. nonalfalfae isolate VnAa140 revealed that Verticillium can spread rapidly from a parent stem into clonal root sprouts. At 1 month postinoculation (MPI), 12 of the $213(5.6 \%)$ monitored stems ( $>0.5 \mathrm{~m}$ tall), including the inoculated parent stem, were symptomatic (Fig. 4). By 2 MPI, the number of symptomatic stems increased to $48(22.5 \%)$, and wilting sprouts were observed $10 \mathrm{~m}$ from the inoculated parent stem. At $3 \mathrm{MPI}$, the second suspected parent stem, which had not been inoculated and was located $3.5 \mathrm{~m}$ from the inoculated parent stem, became symptomatic. By mid-September 2013, 3.5 MPI, 129 stems (60.6\%) were symptomatic. At this time, the inoculated parent stem displayed $99 \%$ crown defoliation (Fig. 4) and many additional unmonitored, smaller root sprouts $(<0.5 \mathrm{~m}$ tall) were wilting and defoliating as a result of the one original inoculation. In June 2014, 12 MPI, the inoculated parent stem was dead and the total number of symptomatic stems increased to 187 (87.8\%) (Fig. 4). V. nonalfalfae was successfully reisolated from all wood chip samples taken from 10 symptomatic stems.

\section{Discussion}

The objectives of this study were to determine if Ailanthus forms functional intraspecific root grafts, how frequently they form, and whether $V$. nonalfalfae isolate VnAa140 can be transmitted through Ailanthus intraspecific root grafts and clonal root systems.

The dye translocation study revealed that Ailanthus forms functional intraspecific root grafts, like many other tree species. A total of 35 receptor stems received dye from just 13 donor stumps, suggesting that Ailanthus not only forms intraspecific root grafts, but that grafts are common and abundant, especially in dense stands. Within the 11-year-old Ailanthus stand LV there were nine receptor stems, indicating that Ailanthus forms functional intraspecific root grafts at a young age, likely resulting from its rapidly expanding lateral root systems early in stand development (34). In the older and denser $A i$ lanthus stand SGL 281, there were 17 receptor stems, indicating that the number of functional intraspecific root grafts and interconnected trees increases with stand age and density, as within other trees species. These direct relationships likely occur because larger root

Table 2. Dye translocation observed within the mixed-aged 37-year-old Ailanthus stand, SGL 322

\begin{tabular}{|c|c|c|c|c|c|}
\hline \multirow[b]{2}{*}{ Plot } & \multirow[b]{2}{*}{$\begin{array}{l}\text { Donor } \\
\text { stump }\end{array}$} & \multicolumn{2}{|c|}{ Receptor stems } & \multicolumn{2}{|c|}{$\begin{array}{c}\text { Nearest } \\
\text { non-receptor stem }\end{array}$} \\
\hline & & & Distance & & Distance \\
\hline ID & $\overline{\mathrm{DBH}(\mathrm{cm})^{\mathrm{a}}}$ & DBH (cm) & stump (m) & DBH (cm) & stump (m) \\
\hline 1 & 20.0 & 12.8 & 1.55 & 5.0 & 1.00 \\
\hline \multirow[t]{2}{*}{2} & 15.2 & 18.7 & 0.65 & 10.6 & 0.60 \\
\hline & & 20.9 & 2.05 & & \\
\hline \multirow[t]{3}{*}{3} & 24.3 & 25.6 & 0.75 & 18.6 & 1.70 \\
\hline & & 20.7 & 1.60 & & \\
\hline & & 23.6 & 2.20 & & \\
\hline 4 & 16.7 & 13.8 & 1.65 & 2.7 & 1.25 \\
\hline \multirow[t]{2}{*}{5} & 14.6 & $8.2^{\mathrm{b}}$ & 1.40 & 3.4 & 1.45 \\
\hline & & 22.3 & 1.55 & & \\
\hline Average & 18.2 & 18.5 & 1.5 & 8.1 & 1.2 \\
\hline
\end{tabular}

${ }^{a}$ The DBH of the stem prior to felling.

${ }^{b}$ Stem was possibly of clonal origin and may not have received dye via intraspecific root graft. 


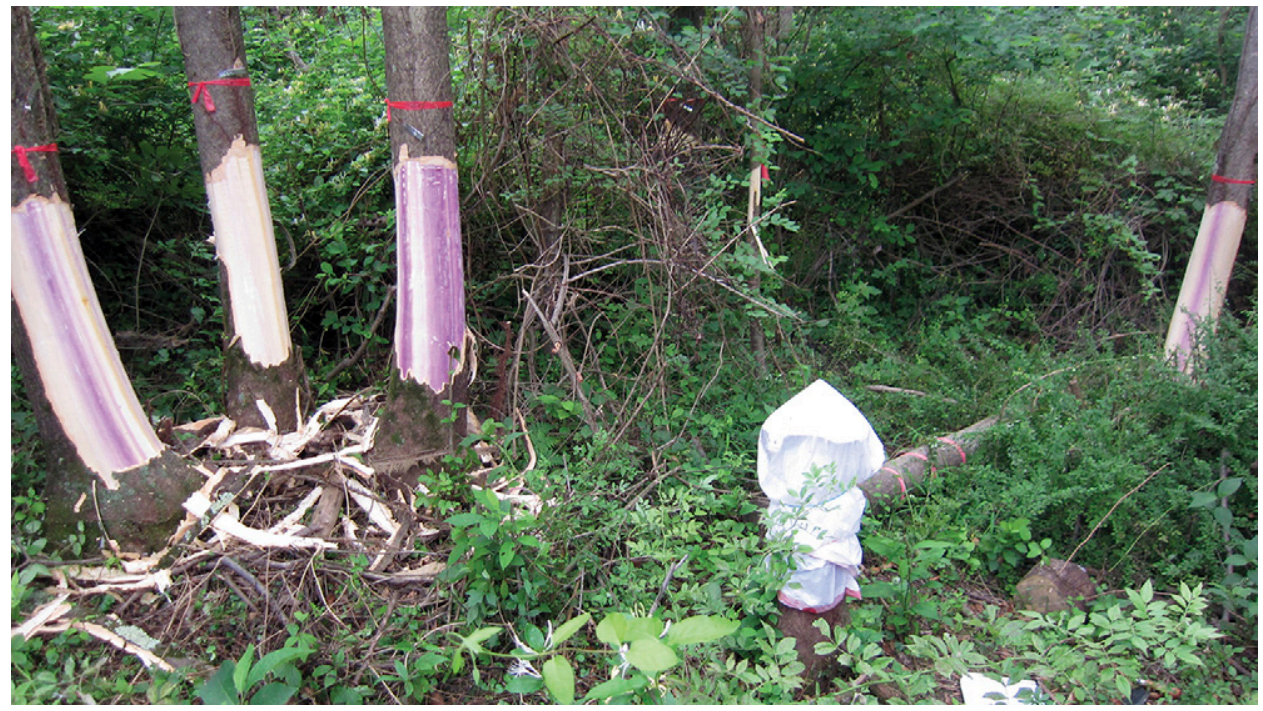

Fig. 2. Dye translocation between Ailanthus stems in Ailanthus stand SGL 281, showing four receptor stems that received dye from the donor stump (shown in the foreground fitted with a covered dye reservoir), indicating the presence of intraspecific root grafts. The receptor stem on the extreme right was $4.0 \mathrm{~m}$ from the donor stump. Multiple streaks of dye were occasionally observed in receptor stems indicating multiple intraspecific root grafts may have been involved in dye translocation.

Table 3. Dye translocation observed within the even-aged 38-year-old Ailanthus stand, SGL 281

\begin{tabular}{|c|c|c|c|c|c|}
\hline \multirow[b]{2}{*}{$\frac{\text { Plot }}{\text { ID }}$} & \multirow[b]{2}{*}{$\frac{\begin{array}{c}\text { Donor } \\
\text { stump }\end{array}}{\text { DBH }(\mathbf{c m})^{\mathbf{b}}}$} & \multicolumn{2}{|c|}{ Receptor stems $\mathbf{s}^{\mathbf{a}}$} & \multicolumn{2}{|c|}{$\begin{array}{c}\text { Nearest } \\
\text { non-receptor stem }\end{array}$} \\
\hline & & $\begin{array}{l}\text { DBH } \\
(\mathbf{c m})\end{array}$ & $\begin{array}{c}\text { Distance } \\
\text { from } \\
\text { donor } \\
\text { stump (m) }\end{array}$ & $\begin{array}{l}\text { DBH } \\
\text { (cm) }\end{array}$ & $\begin{array}{c}\text { Distance } \\
\text { from } \\
\text { donor } \\
\text { stump (m) }\end{array}$ \\
\hline 1 & 21.3 & $\begin{array}{l}15.2 \\
29.1\end{array}$ & $\begin{array}{l}1.00 \\
1.30\end{array}$ & 19.4 & 0.60 \\
\hline 2 & 21.8 & - & - & 28.0 & 1.95 \\
\hline 3 & 25.3 & $\begin{array}{c}5.4^{\mathrm{c}} \\
23.2^{\mathrm{c}} \\
16.9 \\
24.0 \\
20.9 \\
21.3^{2} \\
5.5^{\mathrm{c}} \\
13.3^{\mathrm{c}}\end{array}$ & $\begin{array}{l}0.95 \\
1.35 \\
2.65 \\
3.00 \\
3.00 \\
4.70 \\
4.75 \\
5.00\end{array}$ & 30.2 & 1.95 \\
\hline 4 & 20.7 & $\begin{array}{l}23.5 \\
21.7 \\
25.7 \\
21.2\end{array}$ & $\begin{array}{l}1.75 \\
2.40 \\
2.50 \\
4.00\end{array}$ & 5.5 & 2.15 \\
\hline 5 & 22.3 & $\begin{array}{l}19.2 \\
23.0 \\
23.5\end{array}$ & $\begin{array}{l}1.10 \\
2.35 \\
2.35\end{array}$ & 22.7 & 1.15 \\
\hline Average & 22.3 & 19.6 & 2.60 & 21.2 & 1.56 \\
\hline
\end{tabular}

systems of older trees have a greater probability of coming into contact and forming root grafts with other trees. Also, older trees have had more time to form functional root grafts $(1,7,13,45)$. To our knowledge, this is the first report of functional intraspecific root grafts in A. altissima.

Dye translocation studies do not allow for exact quantification of functional root grafts between or among trees, and generally underestimate the abundance of root grafts. Bormann and Graham (4) presented three ways in which the number of root grafts between trees might be underestimated in dye translocation studies. First, root grafts are only detected by the dye, and the actual number of grafts
Table 4. Number of intraspecific root grafts per excavated Ailanthus root system in stand LV

\begin{tabular}{|c|c|c|c|c|c|c|}
\hline \multirow{2}{*}{\multicolumn{3}{|c|}{ Excavated root systems }} & \multicolumn{2}{|c|}{$\begin{array}{c}\text { Root-grafted } \\
\text { stems }^{\mathbf{a}}\end{array}$} & \multicolumn{2}{|c|}{$\begin{array}{l}\text { Nearest non- } \\
\text { grafted stem }\end{array}$} \\
\hline & & & & Distance(s) & & Distance \\
\hline Stem ID & $\begin{array}{c}\text { DBH } \\
\text { (cm) }\end{array}$ & $\begin{array}{l}\text { Number of } \\
\text { intraspecific } \\
\text { root grafts }\end{array}$ & $\begin{array}{l}\text { DBH } \\
(\mathbf{c m})^{\mathbf{b}}\end{array}$ & $\begin{array}{c}\text { from } \\
\text { excavated } \\
\text { stem }(m)\end{array}$ & $\begin{array}{l}\text { DBH } \\
(\mathbf{c m})^{\mathbf{b}}\end{array}$ & $\begin{array}{c}\text { from } \\
\text { excavated } \\
\text { stem }(m)\end{array}$ \\
\hline 1 & 12.2 & 0 & - & - & 10.2 & 0.75 \\
\hline 2 & 14.3 & 0 & - & - & 18.8 & 1.05 \\
\hline 3 & 12.0 & 1 & 10.3 & 1.35 & 12.4 & 0.85 \\
\hline 4 & 10.4 & 0 & - & - & 15.1 & 1.15 \\
\hline 5 & 14.0 & 2 & 15.5 & 1.50 & 12.4 & 1.85 \\
\hline 6 & 20.2 & 1 & 12.6 & 0.79 & 17.0 & 1.10 \\
\hline 7 & 14.7 & 1 & 13.0 & 1.33 & 12.5 & 1.35 \\
\hline 8 & 13.1 & 1 & 20.0 & 2.04 & 12.4 & 1.00 \\
\hline 9 & 15.0 & 3 & $13.2,13.7$ & $0.75,0.85$ & 10.2 & 1.10 \\
\hline 10 & 16.2 & 2 & 17.4 & 1.02 & $8.3^{\mathrm{c}}$ & 0.90 \\
\hline 11 & 12.6 & 2 & 8.1 & 0.55 & 5.2 & 1.05 \\
\hline 12 & 17.2 & 0 & - & - & 11.5 & 1.40 \\
\hline 13 & 15.4 & 7 & 17.6 & 1.06 & $7.2^{\mathrm{c}}$ & 1.65 \\
\hline 14 & 12.3 & 4 & $15.5,13.8$ & $0.93,1.1$ & 10.4 & 2.10 \\
\hline 15 & 12.3 & 3 & 8.7 & 0.65 & 12.1 & 1.35 \\
\hline 16 & 14.3 & 1 & 23.9 & 1.14 & 14.4 & 1.35 \\
\hline Average & 14.1 & 1.8 & 13.4 & 1.08 & 11.7 & 1.25 \\
\hline
\end{tabular}

a Excavated root systems that formed intraspecific root grafts with multiple neighboring stems have multiple DBH and distance values listed respectively for each root-grafted stem. "-" indicates that no root intraspecific root grafts were discovered.

b For multiple stemmed trees, initial multiple DBH values were each converted to basal area $\left(\mathrm{m}^{2}\right)$ values $\left(\mathrm{BA}=0.00007854 \times \mathrm{DBH}^{2}\right)$, summed, and converted back to a single DBH $(\mathrm{cm})$ value $(\mathrm{DBH}=\sqrt{ }(\mathrm{BA} / 0.00007854))$.

c Stem was dead.

cannot be accurately quantified, since one or more root grafts can contribute to dye translocation from the donor stump to receptor stems. For example, we observed multiple streaks of dye within the xylem of some receptor stems (Fig. 2), suggesting multiple root grafts were involved in dye translocation. Secondly, streaks of dye can occur deeper in the xylem, where they cannot be observed without felling the trees. Since all Ailanthus trees within the dye translocation plots were not felled, we could not detect possible dye translocation in deeper xylem tissues of all stems. Thirdly, when 
several potential receptor stems are grafted to each other, but perhaps only one is directly grafted to the donor stump, the closest receptor stems may preferentially absorb the dye, leaving little for the more distal receptor stems. Dye translocation is at least partially caused by the transpirational pull of receptor stems, which is likely inversely related to distance between the donor stump and receptor stem. Thus, the small amounts of dye translocated to distal receptor stems might not be observed. However, the interconnected trees may still be able to receive agents other than dye, such as wilt pathogens, via translocation through grafted root systems.

In contrast, vegetative root sprouts could receive dye if their parent stem is selected as a donor. Dye may travel from the donor stump, along its root system, and upward into the vegetative sprouts. This coloration might be misinterpreted as translocation via root grafts, resulting in an overestimation of root graft frequency. This form of dye translocation likely occurred within stands SGL 322 and SGL 281 (Tables 2 and 3), where some receptor stems were suspected to be of clonal origin. However, even if some of these stems were indeed clonal, the vast majority $(88.5 \%)$ of the observed receptor stems appeared to receive dye via intraspecific root grafts.

Although dye translocation experiments provide valuable observations and data, they must be considered preliminary in furthering our understanding of Ailanthus' underground growth strategies. Therefore, to physically observe root grafts and further document their frequency within Ailanthus stands, we excavated root systems of 16 Ailanthus stems in the youngest Ailanthus stand, LV. Airspade excavation allowed for targeted excavations that do not damage or disrupt root grafts, unlike previous studies using hydraulic excavating $(7,21,47)$.

Similar to the results of the dye translocation experiment, the excavations revealed that intraspecific root grafts among Ailanthus trees were very common, even in young stands. The 16 excavated root systems in stand LV yielded 28 Ailanthus intraspecific root grafts (1.8 grafts per stem), $75 \%$ of which formed at least one intraspecific root graft, usually with the nearest Ailanthus stem. Self-grafts within $A i$ lanthus root systems were also observed, but potential for interspecific graft formation was likely hindered by Ailanthus' allelopathy, as well as stand LV's lack of tree species diversity.
Proximity appeared to be an important factor governing root graft frequency among Ailanthus stems, as reported for other tree species $(9,42,47)$. If excavation had been feasible and conducted in stand SGL 281, which was denser than stand LV and contained larger and older Ailanthus trees, we hypothesize that perhaps double the number of root grafts would have been observed, as indicated by the difference in the number dye receptor stems between stands LV (nine stems) and SGL 281 (17 stems) (Tables 1 and 3). In support of this idea, our observations and preliminary hand excavations in

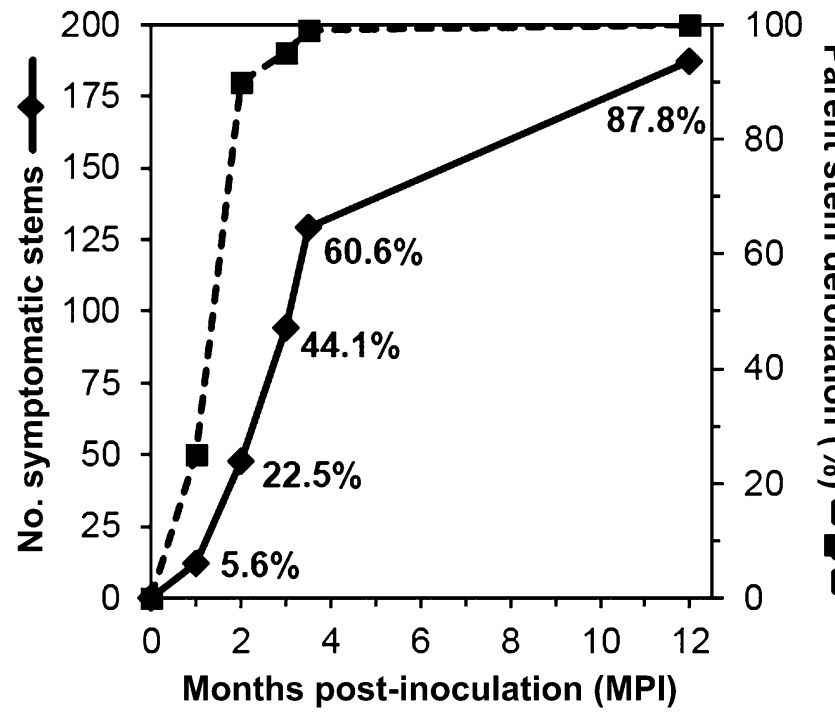

Fig. 4. Disease progression of Verticillium wilt in an artificially inoculated parent stem and surrounding clonal stems. The parent stem was inoculated with Verticillium nonalfalfae isolate VnAa140 in June 2013. All 212 nearby stems ( $>0.5 \mathrm{~m}$ tall), as well as the inoculated parent stem, were monitored for Verticillium wilt symptoms until 12 months postinoculation. Stems were tallied as symptomatic when the total foliage exhibited $>15 \%$ wilt. As a part of each tally, a percentage of symptomatic monitored stems was calculated.
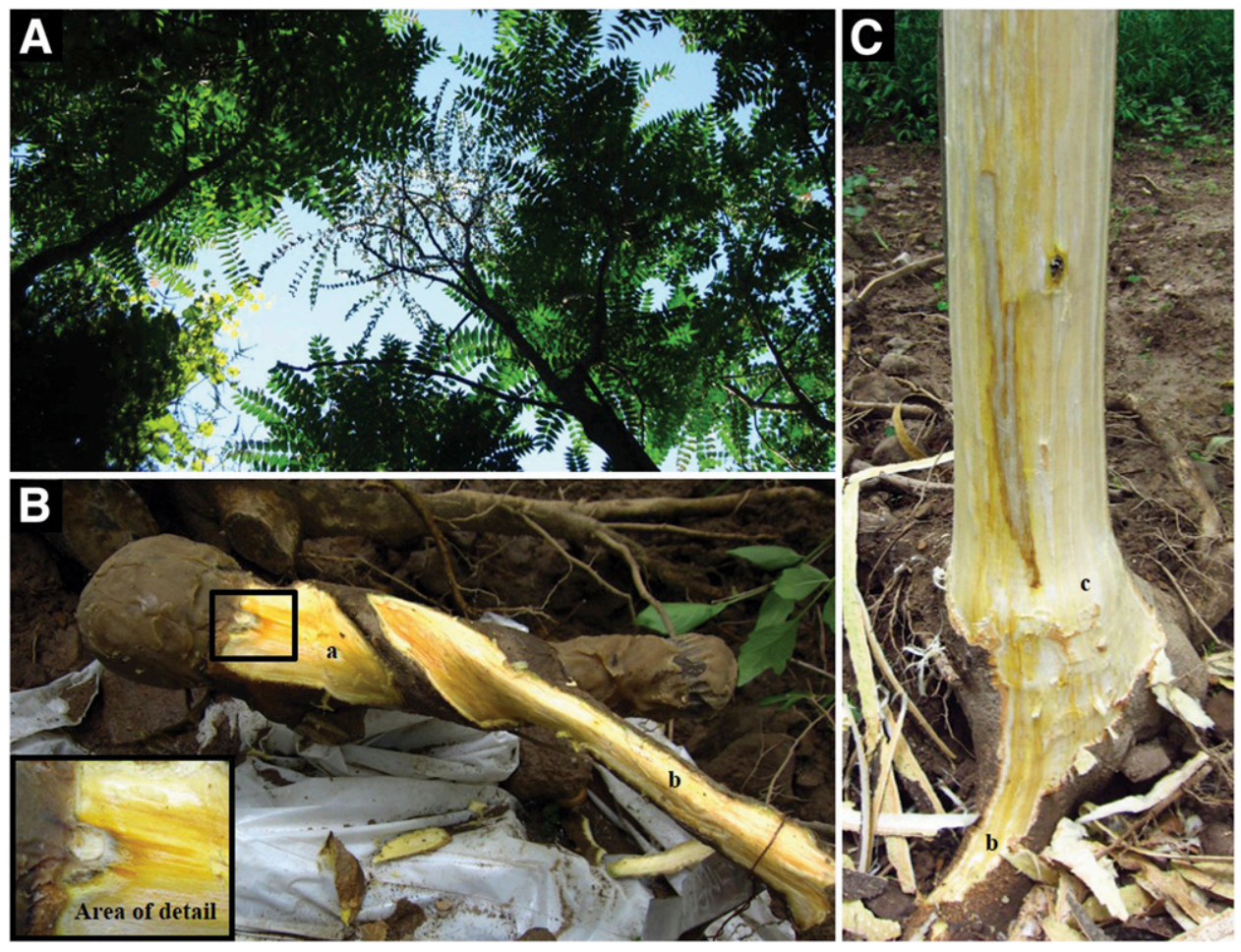

Fig. 3. Transmission of Verticillium nonalfalfae isolate $\mathrm{VnAa} 140$ by an Ailanthus intraspecific root graft, showing $\mathbf{A}$, wilting foliage of a receptor stem, as compared with the foliage of adjacent healthy Ailanthus crowns; B, yellow vascular discoloration in the donor root ("a"), associated with the inoculation wound (area of detail), the receptor root ("b"); and C, the receptor stem ("c"). V. nonalfalfae was successfully reisolated from the donor root and receptor stem. 
stand SGL 281 revealed seven intraspecific Ailanthus root grafts, as well as two living Ailanthus stumps. A living stump is created when a stem dies or is felled, but its root system continues to live and function via root grafts to a nearby healthy tree, and thus is a good indicator of root graft presence $(2,15,50)$.

With intraspecific root grafts, living stumps, and clonal growth, Ailanthus likely forms vast interconnected root systems capable of colonizing large areas, contributing to its invasive nature and ability to compete. In this manner, Ailanthus is similar to trembling aspen (Populus tremuloides Michx.), which is capable of forming large clones that include living stumps and living root systems from stems that have been dead for decades $(7,21)$.

Kowarik (26) reported that clonal growth allows Ailanthus to produce vegetative sprouts that quickly fill canopy gaps within forested environments. Likewise, the interconnectedness of Ailanthus trees via root grafts and living stumps may act similarly. Interconnected root grafts and living stumps likely help Ailanthus maintain a competitive advantage over present or recently established non-Ailanthus tree species by utilizing space and absorbing water and nutrients that competitors would otherwise utilize. Though undoubtedly beneficial for Ailanthus, root grafts can also be detrimental to survival.

Our inoculations confirmed that $V$. nonalfalfae isolate VnAa140 can move from diseased to healthy Ailanthus trees via functional root grafts. However, root graft sampling and dissections conducted in June 2014 revealed that four of the 10 inoculated root grafts were not functional, and thus were not capable of transmitting $V$. nonalfalfae, likely due to the young age of the parent stems. Therefore, only three of the six root graft inoculations, involving functional grafts, resulted in successful transmission to receptor stems, indicating other factors may have limited the success of this novel root graft inoculation technique.

Severing and sealing of the inoculated Ailanthus donor roots may have slowed or stopped the transpirational pull across the graft unions, decreasing translocation of $V$. nonalfalfae inoculum from the donor roots to the receptor roots and stems. Furthermore, severing and sealing the donor roots may have caused the fungus to grow more slowly toward the graft unions, and might help explain time differences observed between inoculation and symptom development among the three symptomatic receptor Ailanthus stems. However, severing the donor roots was essential to ensure that $V$. nonalfalfae would enter the receptor roots and stems only via the graft unions.

Nevertheless, three of the root graft inoculations were successful and confirm that $V$. nonalfalfae can be transmitted from a diseased root to a healthy root by way of intraspecific root grafts. To our knowledge, this is the first report confirming Verticillium transmission from diseased to healthy trees via root grafts for any tree species.

To what level and how quickly Verticillium spp. transmission occurs within Ailanthus stands under natural conditions is difficult to predict, since the speed and efficacy of transmission depends on both frequency and functionality of root grafts between or among $A i$ lanthus trees. Even two Ailanthus trees connected by functional root grafts may not share resources equally, and the deprived tree may decline and eventually die $(3,4,9)$. In addition, if the dominant tree becomes infected first with $V$. nonalfalfae, that tree may decline and $V$. nonalfalfae conidia may be redirected into the previously deprived tree, which may then become the new dominant tree. In contrast, if the inferior Ailanthus tree becomes infected first, $V$. nonalfalfae may transmitted into the dominant tree rapidly due to its stronger transpirational pull. However, regardless of which tree becomes infected first, both connected Ailanthus trees would likely succumb to $V$. nonalfalfae infection soon after the initial infection.

The mean number of receptor stems per donor stump ratio of 2.3 appears to be a useful measure of Ailanthus tree-to-tree connectivity. Use of this ratio allows us to further demonstrate that root graft transmission is likely a major mode of rapid, local $V$. nonalfalfae transmission in high density stands. For example, if 10 trees became infected with $V$. nonalfalfae, they could potentially transmit the pathogen to 2.3 additional trees each. Then all 23 newly infected trees could transmit $V$. nonalfalfae to another additional 2.3 trees each, and so forth in a geometric progression. Since $V$. nonalfalfae can be transmitted to noninoculated healthy trees within 2 to 4 weeks following initial infections (39), root grafts are likely responsible for the rapid epidemics observed within the first growing season in dense stands. Also, root grafts may remain a major mode of $V$. nonalfalfae transmission in following years as the pathogen continues to spread throughout a stand until all grafted Ailanthus have been killed. At that time, long range dispersal of the pathogen, possibly by ambrosia beetles $(23,24)$, may be critical to maintain a more regional epidemic, or to infect isolated Ailanthus trees in the forest or in urban areas.

$V$. nonalfalfae isolate VnAa140 transmission was also evaluated within an Ailanthus clone comprising two parent stems and numerous vegetative root sprouts/suckers. Following inoculation of one parent stem, 128 surrounding sprouts were symptomatic by 3.5 MPI. Symptomatic sprouts occurred at distances ranging from 0.5 to $10 \mathrm{~m}$ from the inoculated parent stem. These results demonstrate that $V$. nonalfalfae is rapidly transmitted from infected parent stems, through their root systems, to surrounding clonal root sprouts. Therefore, the normally advantageous dense clonal growth of invasive Ailanthus serves as a conduit for rapid $V$. nonalfalfae transmission, which can kill entire Ailanthus clones within one or two growing seasons.

Ailanthus root grafts likely play positive roles in site invasion, stand development, dominance over native species, survival, and persistence. However, if an Ailanthus tree comes in contact with a previously unencountered pathogen, such as $V$. nonalfalfae, for which it has not evolved tolerance, root grafting and/or clonal growth habits in dense stands can threaten survival of an entire interconnected population. This weakness can be exploited, allowing for efficient and effective biocontrol of an entire Ailanthus stand using $V$. nonalfalfae.

However, understanding the rapid local transmission of $V$. nonalfalfae through root grafts and clonal root systems is paramount if isolate VnAa140 is to be used as a biological control to curtail growth and spread of the invasive Ailanthus. Transmission of the pathogen in dense stands through connected Ailanthus roots allows for optimized use of applied inoculum of the biocontrol agent. That is, not every Ailanthus tree in a dense stand has to be inoculated with $V$. nonalfalfae, since the pathogen spreads quite rapidly through root grafts and clonal root systems. To efficiently establish $V$. nonalfalfae infections throughout an Ailanthus stand, we propose that large Ailanthus trees with their extensive root systems, in close proximity to other large Ailanthus trees, should be targeted for initial inoculation. Also, entire Ailanthus clones may be controlled by simply inoculating suspected parent stems.

Collectively, this study has expanded knowledge regarding the biology of the invasive Ailanthus tree, as well as transmission of $V$. nonalfalfae through Ailanthus root systems. This knowledge can help optimize the use of $V$. nonalfalfae as a biocontrol agent against Ailanthus. The better we understand transmission of the proposed biocontrol agent, the better we can assess any risks or hazards related to its use.

The results of this study help explain and further demonstrate the effectiveness and efficiency of $V$. nonalfalfae isolate VnAa140 in controlling Ailanthus. In addition to recent host range studies and demonstration that isolate VnAa140 may have become hostadapted to Ailanthus $(24,25,41)$, our results further indicate that low risk is associated with its use in Pennsylvania's forests. V. nonalfalfae should become an effective biological control option for the highly invasive A. altissima, since chemical herbicide applications remain expensive, laborious, and often ineffective.

\section{Acknowledgments}

This research was made possible by funding from the United States Department of Agriculture Forest Service, Forest Health Technology Enterprise Team, Morgantown, WV. We thank K. Wickert for her assistance in the field and laboratory, as well as the Pennsylvania Game Commission, Pennsylvania Department of Conservation and Natural Resources, and the United States Army Corps of Engineers for providing field study sites.

\section{Literature Cited}

1. Basnet, K., Scatena, F. N., Likens, G. E., and Lugo, A. E. 1993. Ecological consequences of root grafting in tabonuco (Dacryodes excelsa) trees in the Luquillo Experimental Forest, Puerto Rico. Biotropica 25:28-35.

2. Bormann, F. H. 1961. Intraspecific root grafting and the survival of eastern white pine stumps. For. Sci. 7:247-256.

3. Bormann, F. H. 1962. Root grafting and non-competitive relationships between trees. Pages 237-246 in: Tree Growth, 1st ed. Ronald Press, New York. 
4. Bormann, F. H., and Graham, B. F., Jr. 1959. The occurrence of natural root grafting in eastern white pine, Pinus strobus L., and its ecological implications. Ecology 40:677-691.

5. Bormann, F. H., and Graham, B. F., Jr. 1960. Translocation of silvicides through root grafts. J. For. 58:402-403.

6. Crandall, B. S., and Baker, W. L. 1950. The wilt disease of American persimmon, caused by Cephalosporium diospyri. Phytopathology 40:307-325.

7. De Byle, N. V. 1964. Detection of functional intraclonal aspen root connections by tracers and excavation. For. Sci. 10:386-396.

8. Dirr, M. A. 1998. Ailanthus altissima. Pages $92-93$ in: Manual of Woody Landscape Plants, 5th ed. Stipes Publishing, Champaign, IL.

9. Eis, S. 1972. Root grafts and their silvicultural implications. Can. J. For. Res. 2:111-120.

10. Epstein, A. H. 1978. Root graft transmission of tree pathogens. Annu. Rev. Phytopathol. 16:181-192.

11. Feret, P. P. 1985. Ailanthus: variation, cultivation, and frustration. J. Arbor. 11:361-368.

12. Fradin, E. F., and Thomma, B. P. H. J. 2006. Physiology and molecular aspects of Verticillium wilt diseases caused by $V$. dahliae and V. albo-atrum. Mol. Plant Pathol. 7:71-86.

13. Fraser, E. C., Lieffers, V. J., and Landhäusser, S. M. 2005. Age, stand density, and tree size as factors in root and basal grafting of lodgepole pine. Can. J. Bot. 83:983-988.

14. Graham, B. F., Jr. 1960. Transfer of dye through natural root grafts of Pinus strobus L. Ecology 41:56-64.

15. Graham, B. F., Jr., and Bormann, F. H. 1966. Natural root grafts. Bot. Rev. 32: 255-292.

16. Heimstra, J., and Harris, D. 1998. Compendium of Verticillium Wilt in Tree Species. Ponsen and Looijen, Wageningen, The Netherlands.

17. Heisey, R. M. 1996. Identification of an allelopathic compound from Ailanthus altissima (Simaroubaceae) and characterization of its herbicidal activity. Am. J. Bot. 83:192-200.

18. Henry, B. W., Moses, C. S., Richards, C. A., and Riker, A. J. 1944. Oak wilt, its significance, symptoms and cause. Phytopathology 34:636-647.

19. Inderbitzin, P., Bostock, R. M., Davis, R. M., Usami, T., Platt, H. W., and Subbarao, K. V. 2011. Phylogenetics and taxonomy of the fungal vascular wilt pathogen Verticillium, with the descriptions of five new species. PLoS ONE 6:e28341.

20. Isaac, I. 1953. The spread of diseases caused by species of Verticillium. Ann. Appl. Biol. 40:630-638.

21. Jelínková, H., Tremblay, F., and DesRochers, A. 2009. Molecular and dendrochronological analysis of natural root grafting in Populus tremuloides (Salicaceae). Am. J. Bot. 96:1500-1505.

22. Kasson, M. T., Davis, M. D., and Davis, D. D. 2013. The invasive Ailanthus altissima in Pennsylvania: A case study elucidating species introduction, migration, invasion, and growth patterns in the northeastern US. Northeast. Nat. 20 (Monogr. 10):1-60

23. Kasson, M. T., O’Donnell, K., Rooney, A. P., Sink, S., Ploetz, R. C., Ploetz, J. N., Konkol, J. L., Carrillo, D., Freeman, S., Mendel, Z., Smith, J. A., Black, A. W., Hulcr, J., Bateman, C., Stefkova, K., Campbell, P. R., Geering, A. D. W., Dann, E. K., Eskalen, A., Mohotti, K., Short, D. P. G., Aoki, T., Fenstermacher, K. A., Davis, D. D., and Geiser, D. M. 2013. An inordinate fondness for Fusarium: Phylogenetic diversity of fusaria cultivated by ambrosia beetles in the genus Euwallacea on avocado and other plant hosts. Fungal Genet. Biol. 56:147-157.

24. Kasson, M. T., O'Neal, E. S., and Davis, D. D. Expanded host range testing for Verticillium nonalfalfae: Potential biocontrol agent against the invasive Ailanthus altissima. Plant Dis. 10.1094/PDIS-04-14-0391-RE.

25. Kasson, M. T., Short, D. P. G., O’Neal, E. S., Subbarao, K. V., and Davis, D. D. 2014. Comparative pathogenicity, biocontrol efficacy, and multilocus sequence typing of Verticillium nonalfalfae from the invasive Ailanthus altissima and other hosts. Phytopathology 104:282-292.

26. Kowarik, I. 1995. Clonal growth in Ailanthus altissima on a natural site in West Virginia. J. Veg. Sci. 6:853-856.

27. Kozlowski, T. T., and Cooley, J. H. 1961. Natural root grafting in northern Wisconsin. J. For. 59:105-107.

28. Lev-Yadun, S. 2011. Why should trees have natural root grafts? Tree Physiol 31:575-578.

29. Lewis, K., and McCarthy, B. 2008. Nontarget tree mortality after tree-ofheaven (Ailanthus altissima) injection with imazapyr. N. J. Appl. For. 25:66-72.

30. McKay, M. B. 1926. Further studies of potato wilt caused by Verticillium albo-atrum. J. Agric. Res. 32:437-470.

31. Miller, J. H. 1990. Ailanthus altissima (Mill.) Swingle. Pages 461-465 in: Silvics of North America. R. M. Burns and B. H. Honkala, eds. Vol. 2: Hardwoods. U.S. Dep. of Agric., Agric. Handb. \#654.

32. Mudge, K., Janick, J., Scofield, S., and Goldschmidt, E. E. 2009. A history of grafting. Hortic. Rev. (Am. Soc. Hortic. Sci.) 35:437-493.

33. Newins, H. S. 1916. The natural root grafting of conifers. Proc. Soc. Am. For 11:394-404.

34. Pan, E., and Bassuk, N. 1986. Establishment and distribution of Ailanthus altissima in the urban environment. J. Environ. Hortic. 4:1-4.

35. Pegg, G. F., and Brady, B. L. 2002. Verticillium Wilts. CAB International, Wallingford, UK.

36. Ploetz, R. C., Pérez-Martínez, J. M., Smith, J. A., Hughes, M., Dreaden, T. J., Inch, S. A., and Fu, Y. 2012. Responses of avocado to laurel wilt, caused by Raffaelea lauricola. Plant Pathol. 61:801-808.

37. Rebbeck, J., Malone, M. A., Short, D. P. G., Kasson, M. T., O’Neal, E. S., and Davis, D. D. 2013. First report of Verticillium wilt caused by Verticillium nonalfalfae on tree-of-heaven (Ailanthus altissima) in Ohio. Plant Dis. 97: 999.

38. Roberts, F. M. 1943. Factors influencing infection of the tomato by Verticillium albo-atrum. Ann. Appl. Biol. 30:327-331.

39. Schall, M. J. 2008. Verticillium wilt of Ailanthus altissima. Ph.D. Dissertation. The Pennsylvania State University, University Park.

40. Schall, M. J., and Davis, D. D. 2009. Ailanthus altissima wilt and mortality: Etiology. Plant Dis. 93:747-751.

41. Schall, M. J., and Davis, D. D. 2009. Verticillium wilt of Ailanthus altissima Susceptibility of associated tree species. Plant Dis. 93:1158-1162.

42. Schultz, R. P., and Woods, F. W. 1967. The frequency and implications of intraspecific root-grafting in loblolly pine. For. Sci. 13:226-239.

43. Snyder, A. L., Kasson, M. T., Salom, S. M., Davis, D. D., Griffin, G. J., and Kok, L. T. 2013. First Report of Verticillium wilt, by Verticillium nonalfalfae, on Ailanthus altissima in Virginia. Plant Dis. 97:837.

44. Snyder, A. L., Salom, S. M., and Kok, L. T. 2014. Survey of Verticillium nonalfalfae (Phyllachorales) on tree-of-heaven in the southeastern USA Biocontrol Sci. Technol. 24:303-314.

45. Stout, B. B. 1961. Season influences the amount of backflash in red pine plantation. J. For. 59:897-898.

46. Talboys, P. W. 1960. A culture-medium aiding the identification of Verticillium albo-atrum and V. dahliae. Plant Pathol. 9:57-58.

47. Tarroux, E., and DesRochers, A. 2010. Frequency of root grafting in naturally and artificially regenerated stands of Pinus banksiana: influence of site characteristics. Can. J. For. Res. 40:861-871.

48. Tarroux, E., DesRochers, A., and Krause, C. 2010. Effect of natural root grafting on growth response of jack pine (Pinus banksiana) after commercial thinning. For. Ecol. Manage. 260:526-535.

49. Verrall, A. F., and Graham, T. W. 1935. The transmission of Ceratostomella ulmi through root grafts. Phytopathology 25:1039-1040.

50. Yli-Vakkuri, P. 1953. Studies of organic root-grafts between trees in Pinus sylvestris stands. [In Finnish] Acta For. Fenn. 60:1-117. 